\title{
HBEGF Gene Product
}

National Cancer Institute

\section{Source}

National Cancer Institute. HBEGF Gene Product. NCI Thesaurus. Code C118379.

A protein encoded by the HBEGF gene. 